\title{
SENSITIVITY OF AEROMONAS OBTAINED FROM POULTRY SOURCES OF DHAKA, BANGLADESH
}

\author{
Saidul Alam* , S. M. R. Hassan, Momena Shirin ${ }^{1}$ and Muhammad Ali Akond ${ }^{2}$ \\ Department of Botany, Jahangirnagar University, Savar, Dhaka-1342, Bangladesh
}

Key words: Aeromonas, Sensitivity, Resistant, Poultry sources, Bangladesh

\begin{abstract}
About $30 \%$ poultry samples harboured Aeromonas spp. Sensitivity tests of 100 selected strains against 12 antibiotics revealed that $20-100 \%$ were resistant to nine and $18-85 \%$ were sensitive to eight antibiotics, respectively. All isolates showed multiple resistance to six to nine antibiotics and thus pose a risk for both chicken farms and public health.
\end{abstract}

Aeromonads are major causative agents of infections in fish as well as in poultry (Austin and Adams 1996) and have been associated with human diarrhoeal disease, wound infections and severe dysentery (Kuhn et al. 1997). The occurrence of different Aeromonas species in foods of animal origin, especially commercially obtained meats have been reported by several investigators (Gill and Jones 1995).

In Bangladesh, poultry meat and eggs are among the most important and popular dishes in the daily diet in addition to their use in many fast food items. Food contamination with antibioticresistant bacteria is a major threat to public health. Among food-borne pathogens, the prevalence of antibiotic resistant strains has increased recently (Chiu et al. 2002) because of indiscriminate use and misuse of antibiotics in food-producing animal farms (Teuber 2001). The present study was designed to isolate Aeromonas from five poultry sources of Dhaka, Bangladesh for assessing their susceptibility patterns to some common antibiotics, conventionally used in Bangladesh.

A total of 150 samples, 30 from each source such as cloacal swabs and intestinal fluid of chicken, egg surface, soil of chicken market and hand wash of chicken salesman from different poultry markets of Mohakhali, New market, Mirpur and Malibag were collected. All the samples were transported to the laboratory immediately in an ice box $\left(4-6^{\circ} \mathrm{C}\right)$. In case of samples of cloacal swab, the test tubes containing APW were incubated for $24 \mathrm{hr}$ at $37^{\circ} \mathrm{C}$.

The isolation of bacteria was done by viable culture method using spread plating, pour plating and membrane filter technique (Akond et al. 2009). For successful isolation of typical colonies, triplicate plates of xylose deoxycholate citrate agar (XDCA) medium (Hi-Media, India) were made and incubated for $24 \mathrm{hr}$ at $37^{\circ} \mathrm{C}$. The isolated cultures were purified by subculture into single identical colonies. Identification was confirmed following standard morphological and biochemical tests of Buchanan and Gibbons (1974).

Sensitivity tests were carried out by single disc diffusion method (Bauer et al. 1966) recommended by the Clinical and Laboratory Standards Institute (CLSI 2005). A total of 12 antibiotic discs (Becton Dickinson, U.S.A.) such as streptomycin $(10 \mu \mathrm{g})$, erythromycin $(15 \mu \mathrm{g})$, chloramphenicol $(30 \mu \mathrm{g})$, ciprofloxacin $(5 \mu \mathrm{g})$, tetracycline $(30 \mu \mathrm{g})$, penicillin $(10 \mu \mathrm{g})$, norfloxacin $(10 \mu \mathrm{g})$, riphampicin $(5 \mu \mathrm{g})$, neomycin $(30 \mu \mathrm{g})$, ampicillin $(10 \mu \mathrm{g})$, nalidixic acid $(30 \mu \mathrm{g})$ and gentamicin $(10 \mu \mathrm{g})$ were used. An inoculum was transferred from a single and well-isolated colony to $2 \mathrm{ml}$ of Mueller-Hinton broth by a sterile inoculating loop and incubated at $37^{\circ} \mathrm{C}$ for 4 $\mathrm{hr}$ to obtain the seed culture. The turbidity of broth culture was then adjusted to a $0.5 \mathrm{McF}$ arland (McFarland 1907) standard with sterile physiological saline water and then a sterile cotton swab

*Corresponding author. <rubelsaidul@yahoo.com> ${ }^{1}$ Institute of Public Health, Mohakhali, Dhaka-1212, Bangladesh. ${ }^{2}$ Present address: Laboratory of Environmental Bioscience, Faculty of Agriculture, Yamaguchi University, Japan 753-8515. 
was dipped into the adjusted suspension and excess broth was purged by pressing and rotating the swab firmly against the inside of the tube above the fluid level. The swab was then spread evenly over the entire surface of the plate of LB agar to obtain uniform inoculums. The plates were then allowed to dry for 3 to 5 minutes.

Antibiotic impregnated discs were then placed on the surface of the seeded plates with a pair of sterile forcep. Five discs (four with antibiotics and one blank disc as control) were placed in each Petri dish, and the diameters of the zones of inhibition in millimeter were measured after 16 to $18 \mathrm{hr}$ of incubation. According to the interpretation table of the Becton Dickinson Microbiology Company of USA, the zone diameter for individual antimicrobial agents was translated into sensitive, intermediate and resistant categories.

The occurrence of Aeromonas in 100 samples is presented in Table 1. All the samples except the one from egg surface, were found to contain Aeromonas spp. About 30\% samples were positive for Aeromonas with incidence range from $20 \%$ in chicken market soil samples to $60 \%$ in cloacal swab (Table 1).

Table 1. Occurrence of Aeromonas in various samples of poultry from Dhaka city. $n=30$

\begin{tabular}{lcc}
\hline Types of samples & $\begin{array}{c}\text { Samples positive for } \\
\text { Aeromonas }\end{array}$ & $\begin{array}{c}\text { Percentage of positive } \\
\text { samples }\end{array}$ \\
\hline Cloaceal swab & 18 & 60 \\
Intestinal fluid & 12 & 40 \\
Egg surface & 00 & 00 \\
Soil of chicken market & 06 & 20 \\
Hand wash of chicken salesman & 09 & 30 \\
\hline Total & 45 & 30 \\
\hline
\end{tabular}

The drug sensitivity pattern of 100 Aeromonas isolates from the samples of poultry sources has been outlined in Table 2. Aeromonas isolates exhibited 25, 65, 70, 75, 82, 8490 and 100\% resistance to chloramphenicol, tetracycline, streptomycin, riphampicin, ciprofloxacin, erythromycin, neomycin and ampicillin and penicillin, respectively and 18, 20, 25, 30, 65, 80, 83 and $85 \%$ isolates were sensitive to ciprofloxacin, tetracycline, riphampicin, chloramphenicol,

Table 2. Sensitivity pattern of 100 selected Aeromonas isolates from poultry sources.

\begin{tabular}{|c|c|c|c|c|c|c|}
\hline \multirow{3}{*}{$\begin{array}{r}\text { Antibiotics } \\
(\text { in } \mu \mathrm{g})\end{array}$} & \multicolumn{6}{|c|}{ Sensitivity and zones of inhibition } \\
\hline & \multicolumn{2}{|c|}{ Resistant } & \multicolumn{2}{|c|}{ Intermediate } & \multicolumn{2}{|c|}{ Sensitive } \\
\hline & $\begin{array}{c}\text { No. of } \\
\text { strains (\%) }\end{array}$ & $\begin{array}{c}\text { Inhibition } \\
\text { zone (mm) }\end{array}$ & $\begin{array}{c}\text { No. of } \\
\text { strains (\%) }\end{array}$ & $\begin{array}{c}\text { Inhibition } \\
\text { zone }(\mathrm{mm})\end{array}$ & $\begin{array}{c}\text { No. of } \\
\text { strains (\%) }\end{array}$ & $\begin{array}{c}\text { Inhibition } \\
\text { zone (mm) }\end{array}$ \\
\hline Streptomycin (10) & 70.00 & $<11$ & 00.00 & $12-14$ & 30.00 & $>15$ \\
\hline Erythromycin (15) & 84.00 & $<13$ & 16.00 & $14-22$ & 00.00 & $>23$ \\
\hline Chloramphenicol (30) & 25.00 & $<12$ & 10.00 & $13-17$ & 65.00 & $>18$ \\
\hline Ciprofloxacin (5) & 82.00 & $<15$ & 00.00 & $16-20$ & 18.00 & $>21$ \\
\hline Norfloxacin (10) & 00.00 & $<12$ & 17.00 & $13-15$ & 83.00 & $>16$ \\
\hline Neomycin (30) & 90.00 & $<12$ & 10.00 & $13-15$ & 00.00 & $>17$ \\
\hline Nalidixic acid (30) & 00.00 & $<13$ & 15.00 & $14-18$ & 85.00 & $>19$ \\
\hline Penicillin (10) & 100.00 & $<28$ & 00.00 & $00-00$ & 00.00 & $>29$ \\
\hline Tetracycline (30) & 65.00 & $<14$ & 15.00 & $15-18$ & 20.00 & $>19$ \\
\hline Ampicillin (10) & 90.00 & $<11$ & 10.00 & $12-14$ & 00.00 & $>15$ \\
\hline Riphampicin (5) & 75.00 & $<15$ & 00.00 & $17-19$ & 25.00 & $>20$ \\
\hline Gentamicin (10) & 00.00 & $<6$ & 20.00 & $7-9$ & 80.00 & $>10$ \\
\hline
\end{tabular}


gentamicin, norfloxacin and nalidixic acid, respectively. None of the 100 isolates was found to be neither resistant to norfloxacin, nalidixic acid and gentamicin nor sensitive to erythromycin, neomycin, penicillin and ampicillin. In addition, 10 to $20 \%$ strains showed intermediate sensitivity to eight antibiotics. All isolates of Aeromonas examined in this study showed multiple resistances to at least six up to nine antibiotics. Similar findings on multiple drug resistance of Aeromonas strains have been reported from different parts of the world (Jennifer et al. 2006). Several survey on utilization of antibiotics in Bangladesh have shown that farmers are habituated in extensive use of various antibiotics as preventive agent against pathogens (Hasan 2004). For this reason, a high frequency of multi drug resistance may occur which eventually replaces the drug sensitive microorganisms (Van de Boogard and Stobberingh 2000).

The scenario of drug resistance in Aeromonas from poultry and poultry environments is alarming, which may pose a risk for both poultry and public health.

\section{Acknowledgement}

The authors are grateful to authorities of Bacteriology Laboratory, Institute of Public Health (IPH), Dhaka, Bangladesh to carry out the present work.

\section{References}

Akond M.A., S. Alam, S.M.R. Hasan, S. Mubassara, S.N. Uddin and M. Shirin. 2009. Bacterial contaminants in carbonated soft drinks sold in Bangladesh markets. J. Food Micrbiol. 130: 156-158.

Austin B. and C. Adams. 1996. Fish pathogens, In: The genus Aeromonas, B. Austin, M. Altwegg, P.J. Gosling and S.W. Joseph (Eds), pp. 197-229. John Willy \& Sons, Chichester.

Bauer A.W.W., M. Kirby, J.C. Sherris and M. Turck. 1966. Antibiotic susceptibility testing by a standardized single disk method. Am. J. Clin. Pathol. 45(4): 493-496.

Buchanan R.E. and N.E. Gibbons (Eds). 1974. Bergey's manual of determinative Bacteriology. Williams and Wilkins, Baltimore.

Chiu C.H., T.L. Wu, L.H. Su, C. Chu, J.H. Chia, A.J. Kuo, M.S. Chien and T.L. Lin. 2002. The emergence in Taiwan of fluoroquinolone resistance in Salmonella enterica serotype Choleraesuis. N. Engl. J. Med. 346: 413-419.

CLSI. 2005. Performance standards for antimicrobial susceptibility testing; 15th informational supplement. CLSI/NCCLS M100-S15. Clinical and Laboratory Standards Institute, Wayne, PA.

Gill C.O. and T. Jones. 1995. The presence of Aeromonas, Listeria and Yersinia in carcass processing equipment at two pig slaughtering plants. Food Microbiol. 12: 135-141.

Hasan S.M.R. 2004. Antibiotic resistance of clinical and environmental isolates of Salmonella spp. from Bangladesh. M. Sc. Thesis, Department of Botany, Jahangirnagar Univ. Savar, Dhaka.

Jennifer R.H., C.Z. John and M.J. Randall. 2006. Antimicrobial Susceptibilities of Aeromonas spp. Isolated from Environmental Sources. Appl. Environ. Microbiol. 72: 7036-7042.

Kuhn I., G. Allestam, G. Huys, P. Janssen, K. Kersters, K. Krovacek and T.M. Stenstrom. 1997. Diversity, persistence and virulence of Aeromonas strains isolated from drinking water distribution systems in Sweden. Appl. Environ. Microbiol. 63: 2708-2715.

McFarland J. 1907. The nephelometer: an instrument for estimating the number of bacteria in suspensions used for calculating the opsonic index and for vaccines. J. Am. Medical Asso. 49(14): 1176-1178.

Teuber M. 2001. Veterinary use and antibiotic resistance. Curr. Opin. Microbiol. 4: 493-499.

Van de Boogard A.E. and E.E. Stobberingh. 2000. Epidemiology of resistance to antibiotics links between animals and humans. J. Antimicrob. Agents. 14: 327-335. 